Original article

Received: 16 October 2016 / Accepted: 20 February 2017

\title{
SURVEY OF THE URBAN BELL IN THE BELFRY OF ST. TRINITY CHURCH IN KROSNO
}

\author{
Grzegorz Oleniacz ${ }^{1}$, Izabela Skrzypczak ${ }^{1}$, Lucjan Ślęczka ${ }^{1}$, \\ Tomasz Świętoń ${ }^{1}$, Marta Rymar ${ }^{2}$ \\ 1) Rzeszów University of Technology, \\ Faculty of Civil and Environmental Engineering and Architecture \\ 2) Historic Preservation Officer in Krosno
}

\begin{abstract}
Urban is one of the three bells in the belfry of St. Trinity Church in Krosno. It is the largest one, with diameter equal to $1,535 \mathrm{~mm}$ and it is commonly considered as one of the largest historical bells in Poland. The total mass of all the three bells is close to 4,200 kilograms, so the dynamic actions produced by swinging have a great effect on the supporting structure and on the tower. However, the exact weight of the biggest bell isn't known, and for safety reasons it should be estimated in order to verify the real dynamic forces affecting the structure. The paper describes the method of Urban bell's survey using terrestrial laser scanning and a total station as a task to estimate its weight by determining its volume.
\end{abstract}

Keywords: volume determining, terrestrial laser scanning

\section{General information}

Bells called Urban, Jan and Maryan, hanging on the bell tower of St. Trinity Church in Krosno, belong to antique bells in Poland. Tower along with the bells constitute the central part of the Old Town of Krosno and it entered on a list of antique buildings at No. 9 - ZN (A-9 / 48) with decision of 21 November 1948. Urban bell is one of the biggest bells in Poland, it was cast in 1639, however the exact weight of the mentioned bell isn't known.

In 2012, the interior of the belfry became publicly available. In the same year, during the bells swinging a clapper of Jan came off. For safety reasons the City Hall of Krosno commissioned the technical expertise of the bells. It turned out that the other two clappers should be replaced too, due to its poor condition and the risk of being wrenched off.

Steel structure directly supporting the bells in the bell chamber is dated to 1928. The total mass of all three bells is close to 4,200 kilograms, so the dynamic forces produced 
by swinging have a great effect on the old steel structure supporting the bells and on the tower. The weight of the Urban bell should be estimated in order to verify the real dynamic forces affecting the structure.

\section{The bell tower and Urban}

The building of the bell tower is one of the most recognizable landmarks in the city of Krosno. Now it stands as a relic and it is currently a popular tourist attraction. For a few centuries it has constituted a specific predominant feature in the panorama of Krosno and has attracted artists' attention. The oldest preserved views come from the XIX century. (Fig. $1 \mathrm{a}$ and b).
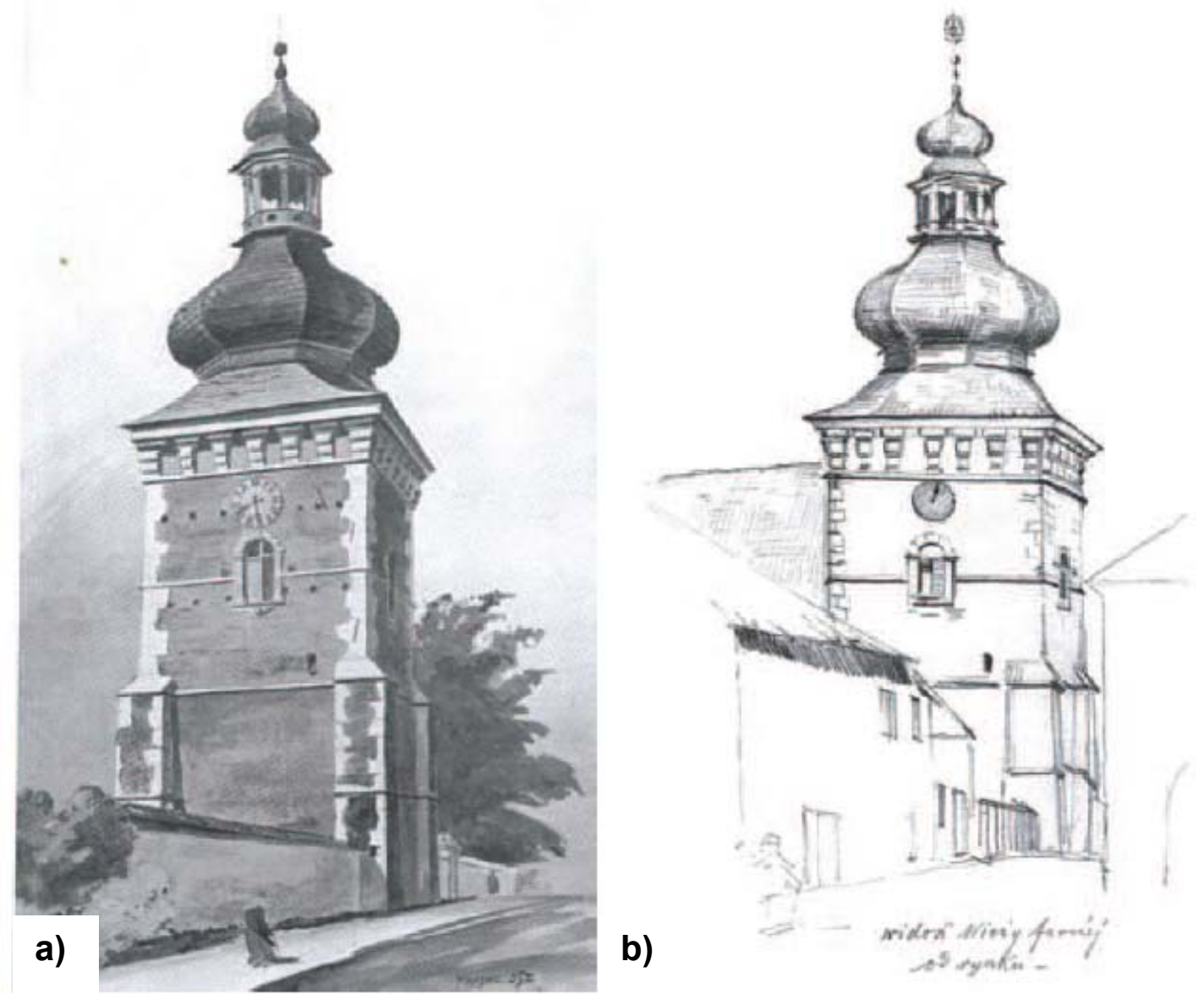

Fig. 1. The views of the belfry, a) Jan Sas-Zubrzycki drawing based on the photo from 1860 (Łopatkiewicz 2016), b)Władysław Maślakiewicz drawing from 1890 (Łopatkiewicz 2016)

The bell tower of St. Trinity Church in Krosno was built between 1637 and 1651. It was founded by Robert Wojciech Portius (Gilbert Porteous Lanxeth), a citizen of Krosno since 1621, a native of Scotland. The main body of the tower possesses a nearly square section with about $8.8 \div 9.0 \mathrm{~m}$ per side (Fig. 2). The main body is made of masonry. The thickness of the walls is $2.2 \mathrm{~m}$ at the wall basement and $1.25 \mathrm{~m}$ at the level of the bells' chamber (+9.54). The tower crown has a timber structure. The total height of the tower is 38.0 m (Rymar, 2015; Rymar \& Ślęczka, 2015) 


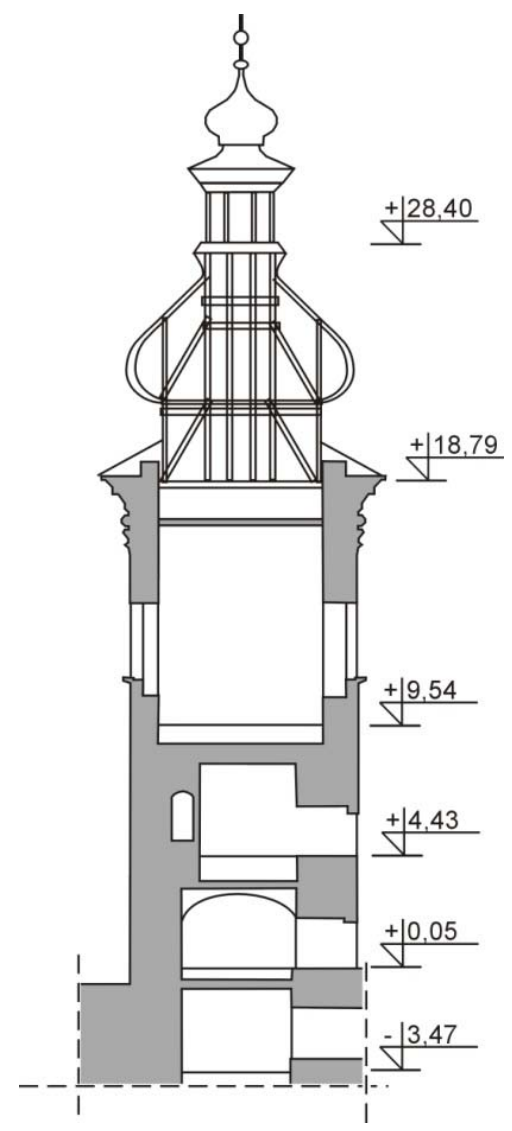

Fig. 2. General diagram of the bell tower

There are three bells in the belfry, Urban, Jan and Maryan, supported by steel yokes and truss structure, (Fig. 3). They were casted in 1639 by Szczepan Meutel and Jerzy Olivier. The largest one is Urban, with diameter equal to $1,535 \mathrm{~mm}$.

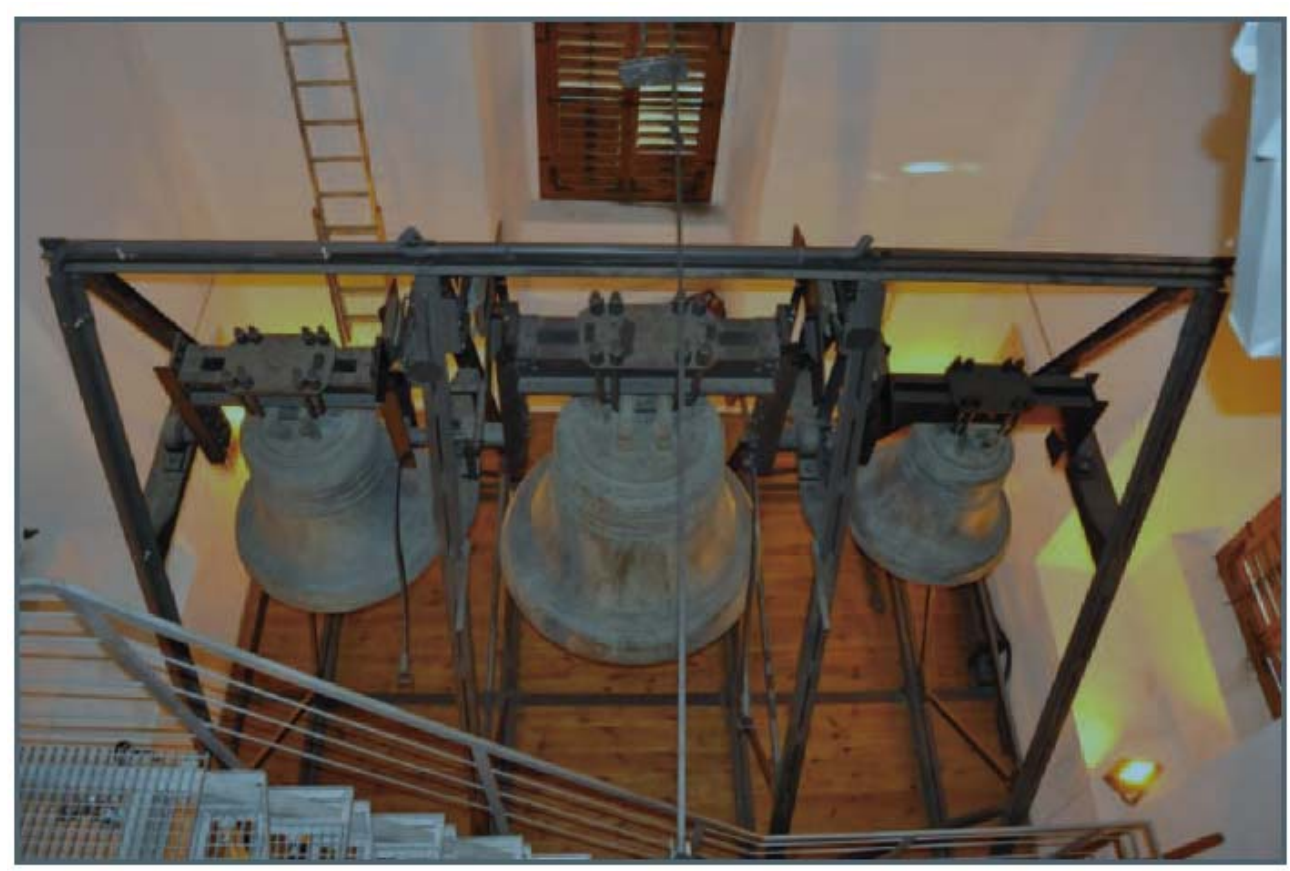

Fig. 3. Steel structure supporting the bells and, from the left side: Jan, Urban and Maryan. Photo by Marta Rymar in 2015 
Urban (Fig. 4 and 5) is considered as one of the largest historical bells in Poland. Larger ones are only The Royal Sigismund Bell in the Sigismund Tower of the Wawel Cathedral in Cracow and Tuba Dei bell hanging in the tower of St. John's Cathedral in Toruń.

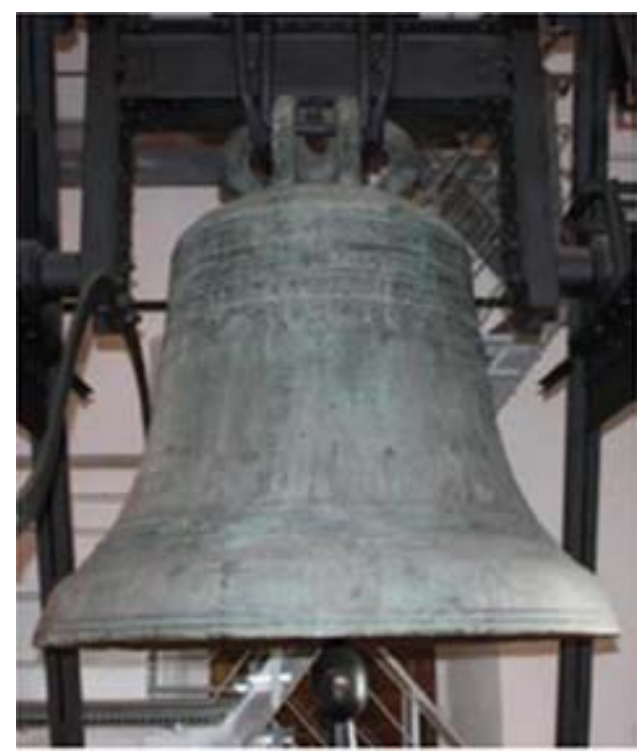

Fig. 4. The Urban bell - general view. Photo by Marta Rymar in 2015

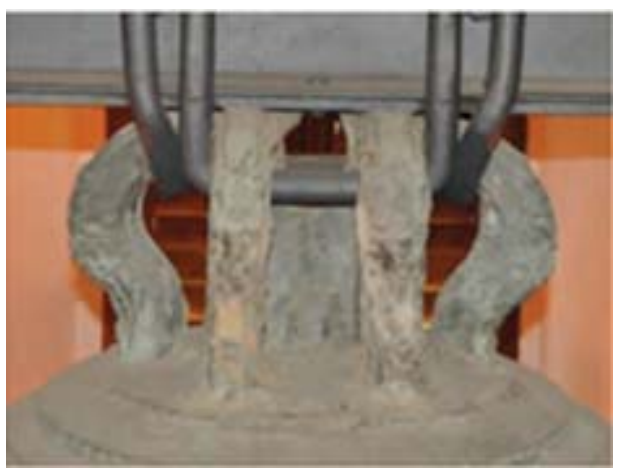

Fig. 5. The Urban's crown with hexagonal bows. Photo by Marta Rymar in 2015

In 1928 bells were subjected to renovation works in the foundry of Karol Szwabe in Białka by Bielsko. At the same time, the suspension structure of the bells was also replaced from wooden for the steel one (fig. 3, Rymar, 2015; Rymar \& Ślęczka, 2015).

\section{Survey of the Urban}

In 2012 the belfry was made available for tourists. In the same year, during the bells swinging a clapper of Jan came off. The City Hall of Krosno commissioned the technical expertise of the bells. It turned out that the other two clappers should be replaced too, due to its poor condition and the risk of being wrenched off.

The total mass of all the three bells coming from the 17 th century, is nearly equal to 4,200 kilograms, so the dynamic actions produced by swinging have a great effect on the supporting steel structure and on the tower.

In order to verify the real dynamic forces affecting the structure, the task of determining the mass of the bell was taken on. To estimate the weight of the bell it was 
proposed to apply an indirect method involving the determination of its volume by terrestrial laser scanning (TLS) and a total station measurement.

Terrestrial laser scanning is a relatively new, modern measurement technology, which is now widely used in many inventory measurements. Measurement possibilities offered by TLS technology make it very versatile so that it is currently one of the fundamental ways of acquiring spatial data to describe the shape of artificial and natural objects of varied geometry (Ratcliffe \& Myers, 2006; Abmayr et al., 2005; Schulz \& Ingensand, 2004).

Scanning was performed using a Faro Focus 3D scanner from a total of 6 positions with a resolution of $6 \mathrm{~mm} / 10 \mathrm{~m}$ and the total station measurement with Trimble M3 1" Total Station from 3 positions (Fig. 6). Unfortunately, we failed to measure the inner surface of the bell with the total station. The instrument was unable to perform measurement of this surface.

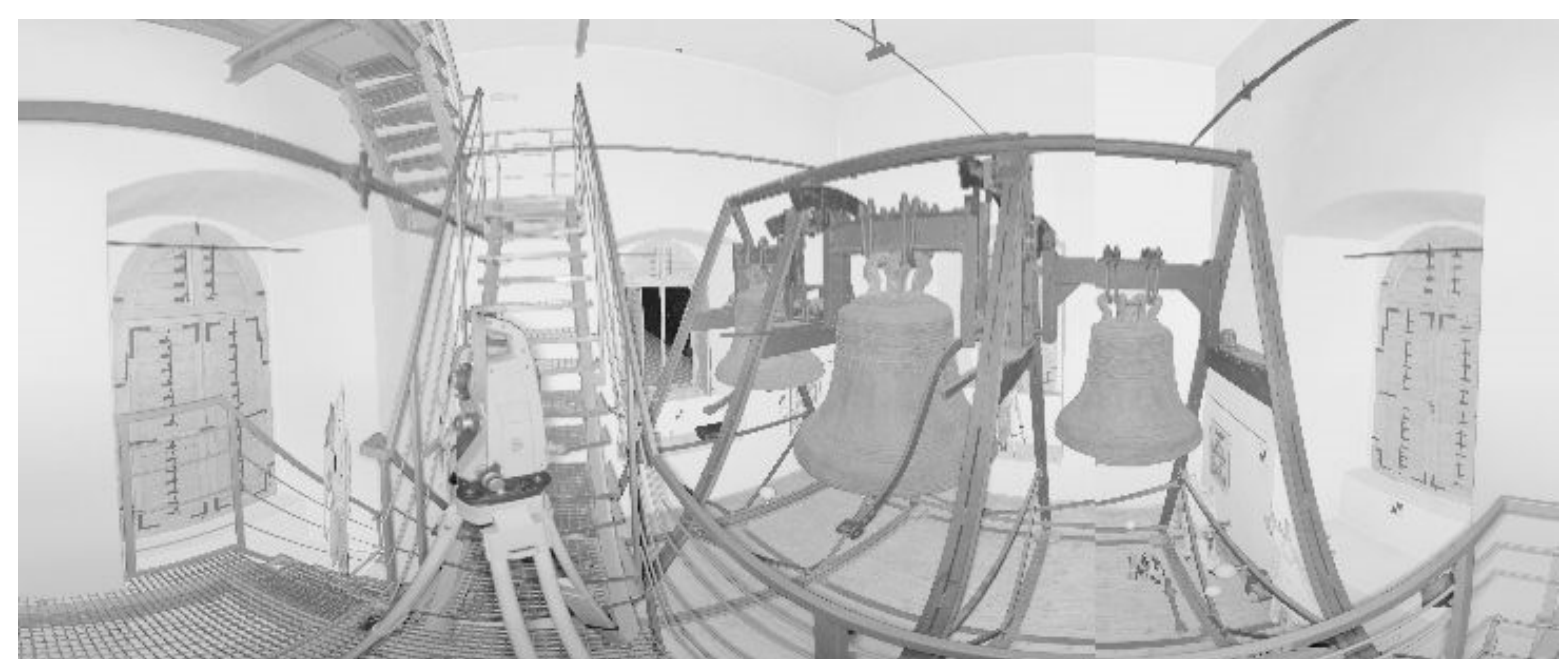

Fig. 6. Fragment of one of the scans with visible position of the total station.

Points measured by the total station were transformed into one common local reference system based on 5 fixed points. Transformation error was $4 \mathrm{~mm}$. The individual scans were combined in Faro SCENE software and exported to AutoCAD package (Fig.7). Average error of fitting does not exceed $4 \mathrm{~mm}$.

It was decided to abandon the mechanical methods because of gaps in the set of points reflecting the outer surface determined by both methods and due to insufficient information about the correctness of mapping the inner surface of the bell and its clapper. Modelling was carried out by manual interpolation of the outer and inner surface. Filtration of points and separation of an object were made in AutoCAD. Both surfaces of the bell were separated too (Fig. 8).

The shape of the bell was interpolated with circular cross-sections on a planar view. Sections were based on the diameters determined from vertical projection oriented in six directions. We managed to create an average of 35 cross-sections in each direction for a scanned point cloud, which gives an average density of $3.5 \mathrm{~cm}$ at the height of the bell (Fig. 9). Due to a smaller set of points from a total station measurement, the number of cross-sections in each direction fluctuated around 20 . Then the space block was stretched on the designated cross-sections (Fig. 9) and its volume was determined. 


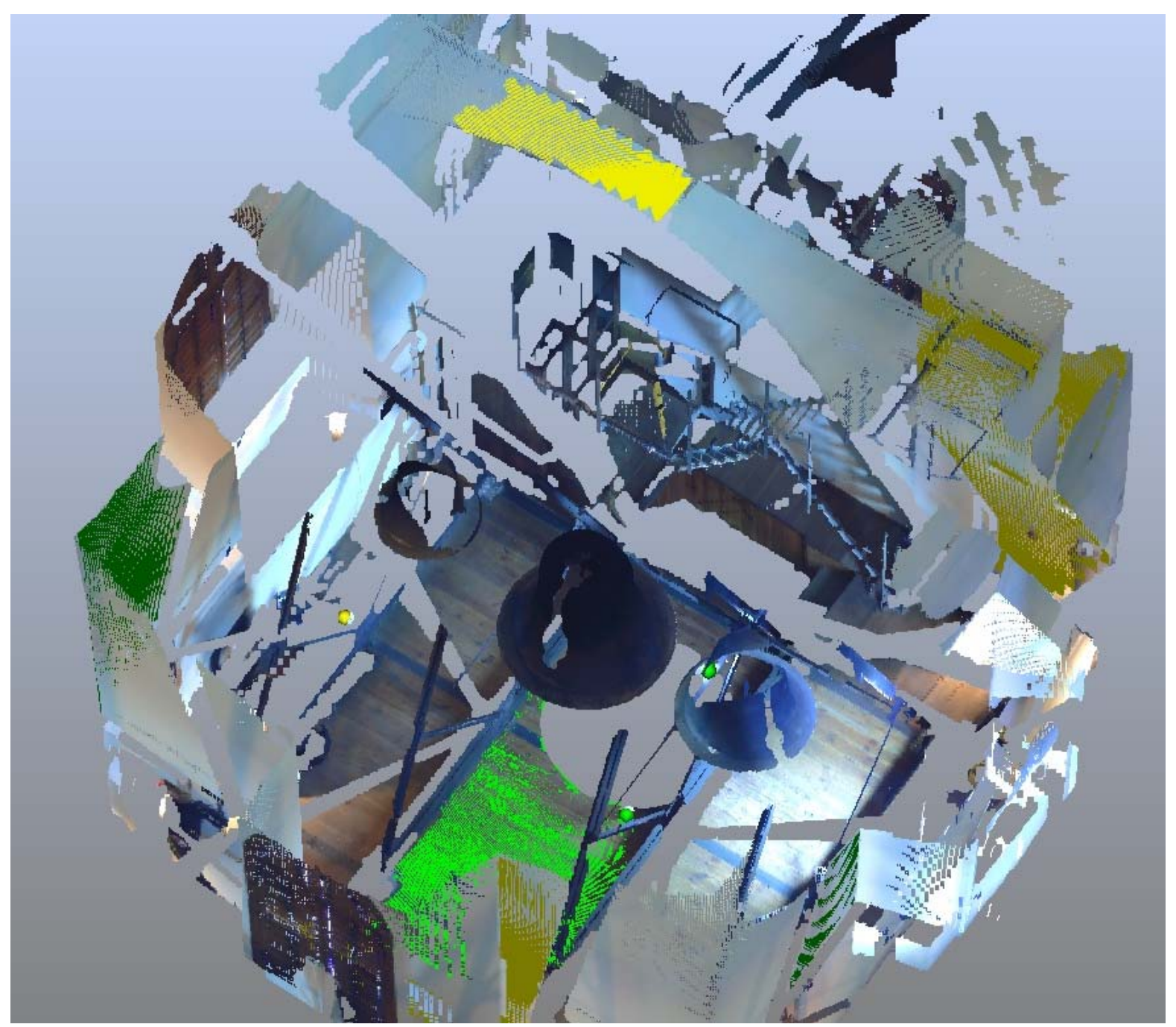

Fig. 7. The point cloud from the scans inside the bell tower
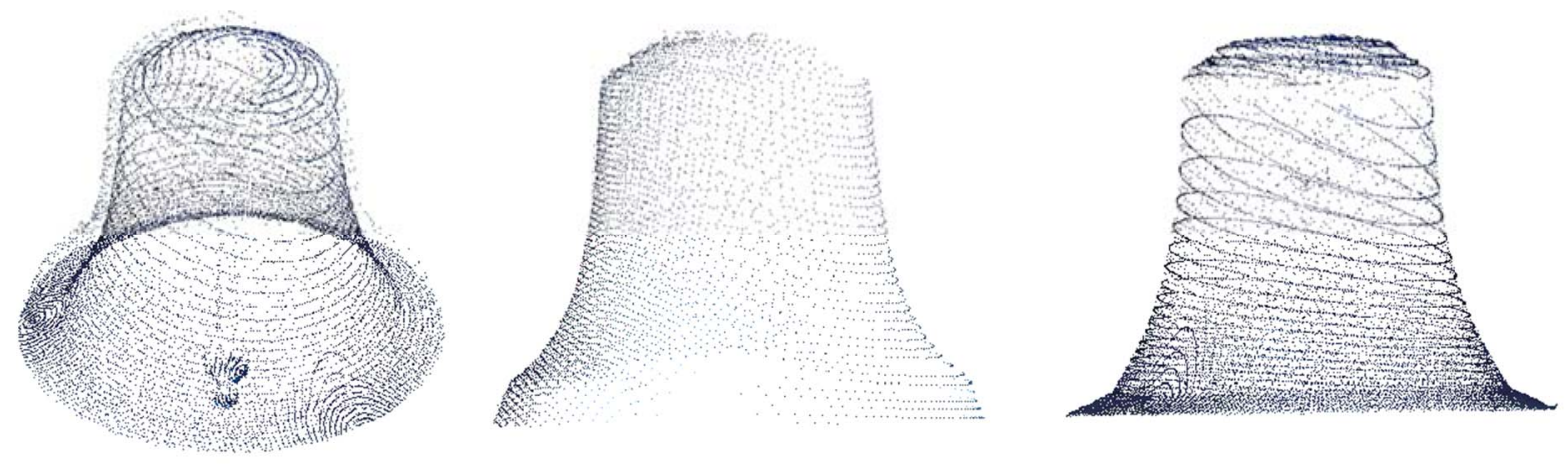

Fig. 8. The point cloud of the Urban bell and its division between the outer and inner surface 

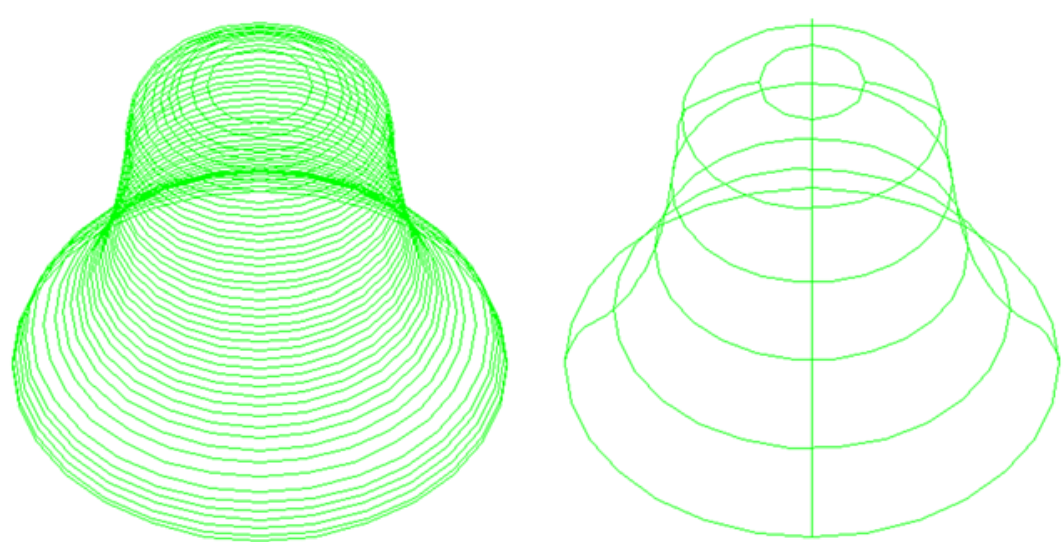

Fig. 9. Example of the outer surface cross-sections and a space block based on it.

The volume of the bell resulted from subtracting the volume limited by the outer and inner surface. The results are shown in the Table 1. As can be seen, lower density of total station measured points gives slightly worse results of interpolation.

Tab. 1. Summary of results

\begin{tabular}{|c|c|c|c|}
\hline No. & $\begin{array}{c}\text { The volume of the } \\
\text { outer surface- } \text { total } \\
\text { station }\left[\mathrm{m}^{3}\right]\end{array}$ & $\begin{array}{c}\text { The volume of the } \\
\text { outer surface- TLS } \\
{\left[\mathrm{m}^{3}\right]}\end{array}$ & $\begin{array}{c}\text { The volume of the } \\
\text { inner surface- TLS } \\
{\left[\mathrm{m}^{3}\right]}\end{array}$ \\
\hline 1 & 1.040 & 1.046 & 0.826 \\
\hline 2 & 1.057 & 1.051 & 0.834 \\
\hline 3 & 1.043 & 1.040 & 0.836 \\
\hline 4 & 1.054 & 1.044 & 0.831 \\
\hline 5 & 1.052 & 1.047 & 0.828 \\
\hline 6 & 1.043 & 1.039 & 0.826 \\
\hline Average value & 1.048 & 1.045 & 0.830 \\
\hline $\begin{array}{c}\text { Standard } \\
\text { deviation }\end{array}$ & 0.008 & 0.005 & 0.005 \\
\hline
\end{tabular}

Thus, the designated volume of the bell was $0.215 \mathrm{~m}^{3}$. Assuming the density of bronze at $8.8 \mathrm{t} / \mathrm{m}^{3}$ (Szymczyk et al., 2003), it gives the weight of $1,900 \mathrm{~kg}$. This is without taking into account the weight of hexagonal bows at the crown of the bell and the clapper of the bell. Clapper of the bell should weigh between $3-4 \%$ of the total weight of the bell.

\section{Conclusions}

We can conclude that the total weight of the bell will be slightly more than 2 tons. This would coincide with the provisions of Sarna priest who, in the Description of Krosno District, stated that according to an inventory of St. Trinity Church in Krosno in 1785 Urban weighed 50 hundredweight (Sarna, 2006). The hundredweight in the former Galician units system weighed $40.55 \mathrm{~kg}$.

Due to the fact that we failed to perform a measurement of the inner surface with a total station, the other independent method should be performed to verify the weight of Urban. It should also be noted that the lower density of total station measured points of the outer surface causes slightly worse results of manual interpolation. 


\section{References}

Rymar M. (2015). Inwentaryzacja i ocena nośności stalowej konstrukcji wsporczej dzwonów na wieży kościoła p.w. Trójcy Przenajświętszej w Krośnie, MSc thesis, PWSZ im. S.Pigonia w Krośnie

Rymar M. \& Ślęczka, L. (2015). Resistance and durability analysis of steel supporting structure on the bell tower of St. Trinity Church in Krosno, Journal of Civil Engineering, Environment and Architecture, t. XXXII, z. 62 (4/15), 2015, pp. 405415

Łopatkiewicz, T. (2016). Dziewiętnastowieczna ikonografia kościoła Świętej Trójcy w Krośnie. In F. Leśniak (Ed.) Krosno Studia z dziejów miasta i regionu, Vol. VII (pp. 137 - 190). Krosno: Wydawnictwo Ruthenus

Ratcliffe, S. \& Myers, A. (2006). Laser scanning in the open pit mining environment a comparison with photogrammetry, I-SiTE Product Development White Paper

Abmayr, T., Hartl, F., Reinkoster, M. \& Frohlich, C. (2005). Terrestrial Laser Scanning - applications in Cultural Heritage Conservation and Civil Engineering. International Archives of Photogrammetry, Remote Sensing and Spatial Information Science, Vol. XXXVI, Part 5/W17

Schulz, T. \& Ingensand, H. (2004). Terrestrial Laser Scanning - Investigations and Applications for High Precision Scanning, FIG Working Week 2004, Athens, Greece, May 22-27, 2004, Retrieved from https://www.fig.net/resources/proceedings/fig_proceedings/athens/papers/

Szymczyk, T., Rabiej, S., Pielesz, A. \& Desselberger, J. (2003). Tablice matematyczne fizyczne chemiczne astronomiczne, Wydanie wspólne PPU PARK i Świat Książki

Sarna, W. (1898). Opis powiatu krośnieńskiego pod względem geograficznohistorycznym, Nakład autora i prenumeratorów z drukarni Józefa Styfiego

\section{Authors:}

Grzegorz Oleniacz 1), oleniacz@prz.edu.pl

Izabela Skrzypczak 1), izas@prz.edu.pl

Lucjan Ślęczka ${ }^{1)}$, sleczka@prz.edu.pl

Tomasz Świętoń ${ }^{1)}$, swieton@prz.edu.pl

Marta Rymar ${ }^{2)}$, rymar.marta@um.krosno.pl

1) Rzeszów University of Technology

Faculty of Civil and Environmental Engineering and Architecture

ul. Poznańska 2, 35-084 Rzeszów, Poland

2) Historic Preservation Officer in Krosno

ul. Staszica 2, 38-400 Krosno, Poland 